\title{
THE DIGITAL MOVE TOWARDS ONLINE LEARNING IN LEBANON
}

\author{
Layal HAMADE \\ Bucharest University of Economic Studies, Bucharest, Romania \\ layal.hamade@liu.edu.lb
}

\begin{abstract}
Face-to-face learning has always been the primary way of education in Middle East. However, some countries such as Jordan, Saudi Arabia, UAE and others decided to adopt some learning management platforms to provide dual programs online. On the other hand, Lebanon is still in its early stages as it was adopted by Ministry of Education in mid-2020 due to the spread Covid-19. In addition, utilizing online learning platforms suffer from many challenges such as accreditation, culture, cost, etc. To study students' satisfaction regarding technology use, level of interaction, types of questions, training, and online sessions and recorded voice-over slides, a survey was distributed to 609 Lebanese students attending different universities. It showed that institutions mainly used Moodle, Google Classroom, and Zoom. There was a comparable rate of satisfaction between Google and Moodle platforms; however, a lower rate with Zoom.
\end{abstract}

Keywords: Online learning, Lebanon, learning management system, universities, satisfaction.

\section{INTRODUCTION TO E-LEARNING}

Education strategies have been changing for decades. Profits, market development, reputation and image, and lately Covid-19 pandemic all have moved education towards using online platforms for education. In definition, any education that takes place using the Web is called e-learning or online learning. Online learning is considered one of the types of something called distance learning that gathers all the learning activities that occurs through distance and not using the traditional study hall (Stern, n.d.). It includes securing of information and abilities utilizing electronic innovations, for example, PC and web. One advantage of online learning is that it empowers learners and teachers to adapt to it anytime and regardless of the geographic place (Mohammed et al., 2017). According to Stern (n.d.), and Mohammed et al. (2017), benefits of online learning include:

a. Ability to be conducted anytime and anywhere with no need to come and go and search for parking lots. 
b. Enhancing learner-to-learner and learner-to-teacher interactions leading to more active listening and better student-focused learning conditions.

c. Ability to use various learning styles and technological techniques leading to better course material understanding and more discussions with enhancement in student technological, writing, and life skills.

d. Sections can fit in a larger number of students from different places decreasing the need of a physical infrastructure.

e. Ability to expand globally and target new markets thus growing registrations.

E-learning can be categorized into two groups: synchronous and asynchronous.

a. Synchronous: It is a teacher-driven way of learning that takes place through an ongoing, instant learning process using the internet with both learners and teachers necessity presence (Mohammed et al, 2017). Techniques usually adopted include but not limited to video/audio conferencing, texting or chat, instant messaging (IM), live webcasting, application sharing, whiteboard, virtual classrooms, etc. (Soni, 2015). This makes it workable for instructors and understudies to convey and impart information or thoughts to quick reaction. Advantages of this type include the ability to get direct responses through online engagement and enhancement of student social skills due to their interactions with their teachers. However, one disadvantage includes less time flexibility (Mohammed et al., 2017).

b. Asynchronous: It is a self-study system that can take place offline, thus with or without the attendance of instructors or students where material is delivered through the internet or by email. Advantages of this type include the flexibility in time, ability to fit in busy schedules, and enhancement in students' cognitive processing (Mohammed, 2017). This type can be delivered through Self-paced (SCORM), Audio/Video, E-mail, Discussion forum, Wiki/Blog, Webcasting/Conferencing, Computer-based training (CBT) and Webbased training (WBT), Simulations, Game-based learning (Soni, 2015). The main disadvantage is the low level of interaction and communication where learners sense that they are learning by themselves (Mohammed et al., 2017). 
Hamade, L.

THE DIGITAL MOVE TOWARDS ONLINE LEARNING IN LEBANON

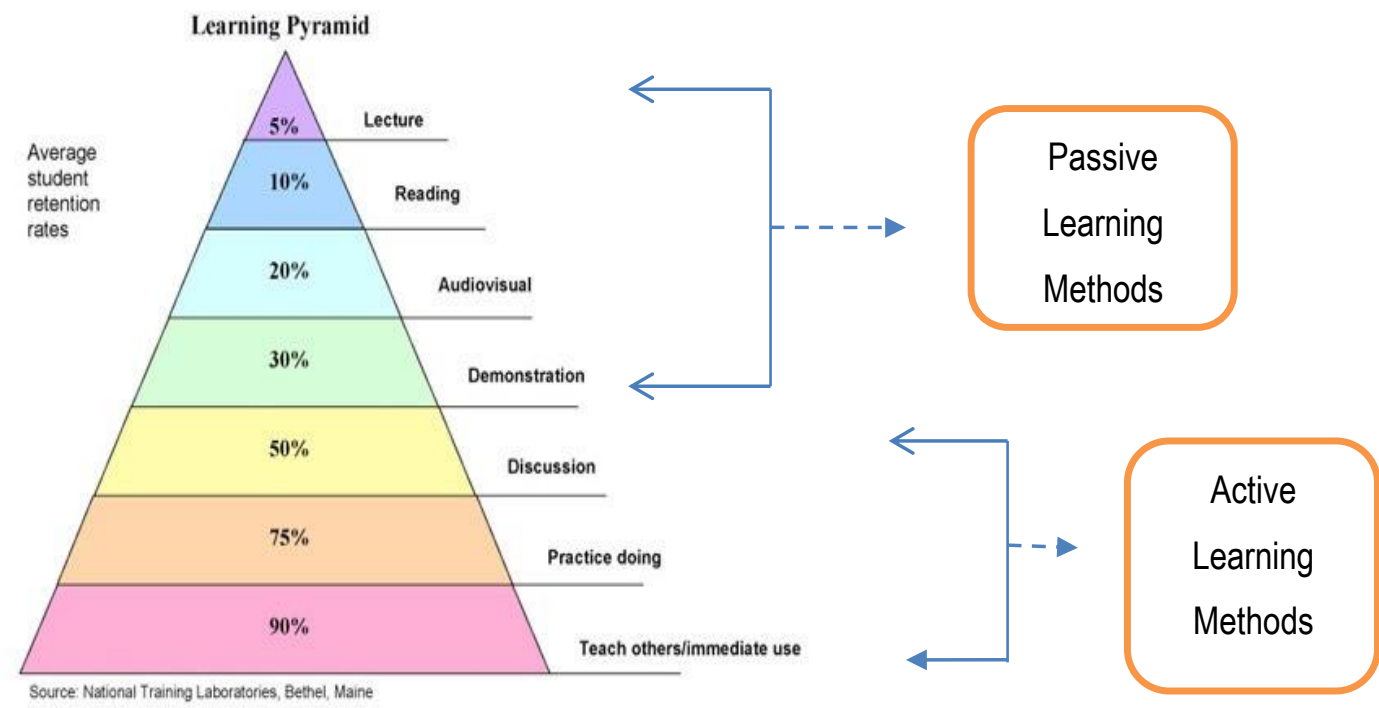

FIGURE 1. LEARNING PYRAMID

Source: Soni (2015)

Digital technology use in education is known to be computerized frameworks that support dynamic learning, information development, request, and investigation with respect to the students, and which take into consideration remote correspondence just as information sharing to occur among educators and students in various physical study hall areas (UCLES, 2017).

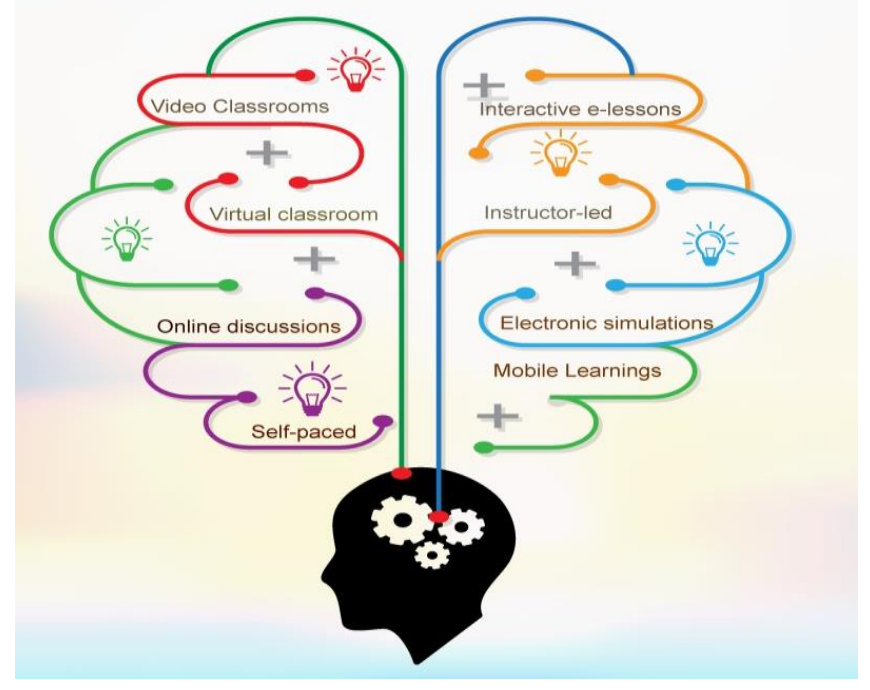

FIGURE 2. E-LEARNING METHODS

Source: Soni (2015) 


\section{LEARNING MANAGEMENT SYSTEM}

Learning management system (LMS) is defined as an interactive internet-based software platform that enhances the provision of course materials and activities to learners without the need for their physical presence in the classroom (Learning Management System, 2014).

\subsection{LMS Features}

According to TrustRadius (2020), learning management system features can be divided into main features used in education sector and other features that can be used beyond education to cover business/corporate organizations.

These features are:

\begin{tabular}{|c|c|c|c|}
\hline \multicolumn{2}{|r|}{ * Content creation and management } & \multicolumn{2}{|c|}{ Others include: } \\
\hline & Assessment & & \\
\hline & management & $\nLeftarrow$ & Social media support \\
\hline & Learning object repository (LOR) & 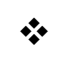 & Mobile app \\
\hline & Grading and feedback tools & 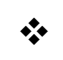 & Blended learning support \\
\hline & Course management & $\nLeftarrow$ & Gamification tools \\
\hline & Student and instructor portals & $\star$ & E-commerce support \\
\hline & Collaboration tools & & \\
\hline & Progress data and analytics & & \\
\hline & SCORM/AICC & & \\
\hline
\end{tabular}

\subsection{LMS Platforms}

\subsubsection{Blackboard (www.blackboard.com)}

It is one of the most utilized frameworks adopted by educational institutions internationally. It is an online learning system created by Blackboard Inc. It is a kind of internet-based software that enables institutions to manage courses, to tailor-make computer architecture which is designed to make adding, upgrading, and swapping components easy and to adapt designs that permits coordination with learners' data frameworks and validation agreements. It might be introduced on local servers or facilitated by Blackboard ASP Solutions (Zaki \& Zawaidy, 2014).

Blackboard is a platform that allow users to post announcements, chat, hold discussions, send mails, create course content and post different lessons, post due dates on calendars, announce, solve, and submit quizzes, exams, and assignments, post grades, videos, and other medias (Zaki \& Zawaidy, 
2014). The adequacy of Blackboard lays on more cognitive, intuitive internet learning situations; and the capacity to configure learning exercises which can subjectively draw in the student, and lead them to consider the course content that are posted, as far as explanation, significance, application and settings (Alokluk, 2018). Using Blackboard Learn, students can accept or refuse posts sent to their emails and through drop boxes, they can send their assignments; however, they will not get any email notification regarding their courses. In addition, students can share their personal files' information with their colleagues where the administration has the authority to limit each user's disk space. Another tool in Blackboard Learn is the students' ability to search through discussion threads (Subramanian et al., 2014).

Although Blackboard is widely used; however, there are some limitations that expose it to high competition. Blackboard is considered hard-to-use technology whether by the instructors or by the students. Some faculty members consider it as time-consuming and inflexible. Students and faculty found that Blackboard software is hard to learn and adapt to. In addition, Blackboard is considered a fixed platform that provides restricted formats to use, unlike the open-source platforms. Moreover, Blackboard new features were reported to be restricted for use to those who operate it on Microsoft NT servers and since Blackboard depends on server portal, thus it is subject to network problems and decreased level of security as the system can crash. Another issue to rise with Blackboard is its cost where institutions have to pay for the software, hardware, subscription license and for a staff to manage it. (Alokluk, 2018; Bradford et al., 2007).

\subsubsection{Google sites (sites.google.com)}

Google Classroom is a web-based platform used for online learning. It is utilized by schools or universities that have Google Apps for Education and it can be opened through PCs and cell phones, visiting the website at https://classroom.google.com or download the app via Play Store on android or iOS app store. In addition to being free of charge, Google Classroom has fast, and easy-to-use settings and it features high interaction and communication between students and instructors, for example, sending notifications to students about classes and activities and students posting feedbacks on chat stream. Moreover, Google classroom has centralized data storage where instructors' work is saved on cloud, students' material in specific folders, and grades in the application itself (Alim et al., 2019).

On the other hand, Google Classroom has some disadvantages. To assist video-sharing, Google Classroom and YouTube are integrated; however, this integration is missing with Slideshare and Facebook. In addition, activity feeds are not automatically updated causing users to omit some announcements. Another disadvantage is the inability of users to log in to Google Classroom through 
their personal Gmail where they have to log out from their Gmail and log in to Google Classroom in order to share files (Rahman, 2020).

\subsubsection{Moodle (moodle.org)}

It is an Open Source Software (OSS) where users can download, use, modify, and share it for free. It is a Course Management System (CMS) and a Virtual Learning Environment (VLE) that allows instructors to create their online classes and material (Al-Ajlan \& Zedan, 2008). Moodle includes the following:

- $\quad$ Resources tab: It is used to create labels (headings), web pages/text pages, links, and directories (folders) (Al-Ajlan \& Zedan, 2008).

Activity tab: It is used to establish assignments, chat (real-time discussions), choice (Instructors' questions with multiple responses to choose from), database (tables uploaded by the instructor and filled by the student), forums (used to post responses), glossary, lesson (added lessons with questions at the end of each lesson page for students to answer and move on to the next page), quiz, survey, wiki (referring to super-fast which is the speed of creating and updating pages), and SCROM (a bundle of packages of web pages, graphics, Javascript software, quizzes, etc.) (Williams et al., 2007 \& Al-Ajlan \& Zedan, 2008)

According to Monarch Media (2010), although Moodle rates high for its ease of use and installation; however, it has several drawbacks. Users suffer from limited options when it comes to customization and rebranding where they need to have knowledge at the coding level. Moreover, Moodle is set to be used by small and medium-sized corporations as large corporations require full-featured robust competency and development management options that are missing in Moodle. In addition, Moodle depends heavily on third parties' add-ons which are time-consuming when maintaining and updating the software.

Tables 1, 2, and 3 compare different LMS platforms according to three main features: learner tool, support tool, and technical specifications.

TABLE 1. COMPARING DIFFERENT PLATFORMS ACCORDING TO LEARNER TOOL

\begin{tabular}{|l|l|l|l|l|l|l|l|l|l|}
\hline Tool/Platform & Docebo & Schoology & Blackboard & Moodle & $\begin{array}{l}\text { ATutor } \\
2.0\end{array}$ & Edmodo & D2L & $\begin{array}{l}\text { Google } \\
\text { Site }\end{array}$ \\
\hline \multicolumn{1}{|l|}{ Communication Tools } \\
\hline $\begin{array}{l}\text { Discussion } \\
\text { forums }\end{array}$ & $\mathrm{Y}$ & $\mathrm{Y}$ & $\mathrm{Y}$ & $\mathrm{Y}$ & $\mathrm{Y}$ & $\mathrm{Y}$ & $\mathrm{Y}$ & $\mathrm{Y}$ \\
\hline $\begin{array}{l}\text { Discussion } \\
\text { management }\end{array}$ & $\mathrm{Y}$ & $\mathrm{Y}$ & $\mathrm{Y}$ & $\mathrm{Y}$ & $\mathrm{Y}$ & $\mathrm{Y}$ & $\mathrm{Y}$ & $\mathrm{Y}$ \\
\hline File exchange & $\mathrm{Y}$ & $\mathrm{Y}$ & $\mathrm{Y}$ & $\mathrm{Y}$ & $\mathrm{Y}$ & $\mathrm{Y}$ & $\mathrm{Y}$ & $\mathrm{Y}$ \\
\hline
\end{tabular}


Hamade, L.

THE DIGITAL MOVE TOWARDS ONLINE LEARNING IN LEBANON

\begin{tabular}{|l|l|l|l|l|l|l|l|l|}
\hline Internal Email & $\mathrm{Y}$ & $\mathrm{Y}$ & $\mathrm{Y}$ & $\mathrm{N}$ & $\mathrm{Y}$ & $\mathrm{N}$ & $\mathrm{Y}$ & $\mathrm{Y}$ \\
\hline Online Journal & $\mathrm{Y}$ & $\mathrm{Y}$ & $\mathrm{Y}$ & $\mathrm{Y}$ & $\mathrm{Y}$ & $\mathrm{Y}$ & $\mathrm{Y}$ & $\mathrm{Y}$ \\
\hline Real-time Chat & $\mathrm{Y}$ & $\mathrm{Y}$ & $\mathrm{Y}$ & $\mathrm{Y}$ & $\mathrm{Y}$ & $\mathrm{Y}$ & $\mathrm{Y}$ & $\mathrm{Y}$ \\
\hline Whiteboard & $\mathrm{Y}$ & $\mathrm{Y}$ & $\mathrm{Y}$ & $\mathrm{Y}$ & $\mathrm{Y}$ & $\mathrm{Y}$ & $\mathrm{Y}$ & $\mathrm{Y}$ \\
\hline Video services & $\mathrm{Y}$ & $\mathrm{Y}$ & $\mathrm{Y}$ & $\mathrm{Y}$ & $\mathrm{Y}$ & $\mathrm{Y}$ & $\mathrm{Y}$ & $\mathrm{Y}$ \\
\hline
\end{tabular}

ii. Productivity Tools

\begin{tabular}{|l|l|l|l|l|l|l|l|l|}
\hline Bookmarks & $\mathrm{Y}$ & $\mathrm{Y}$ & $\mathrm{Y}$ & $\mathrm{Y}$ & $\mathrm{Y}$ & $\mathrm{Y}$ & $\mathrm{Y}$ & $\mathrm{Y}$ \\
\hline Calendar & $\mathrm{Y}$ & $\mathrm{Y}$ & $\mathrm{Y}$ & $\mathrm{Y}$ & $\mathrm{Y}$ & $\mathrm{Y}$ & $\mathrm{Y}$ & $\mathrm{Y}$ \\
\hline Orientation/Help & $\mathrm{Y}$ & $\mathrm{Y}$ & $\mathrm{Y}$ & $\mathrm{Y}$ & $\mathrm{Y}$ & $\mathrm{Y}$ & $\mathrm{Y}$ & $\mathrm{Y}$ \\
\hline $\begin{array}{l}\text { Searching within } \\
\text { course }\end{array}$ & $\mathrm{N}$ & $\mathrm{N}$ & $\mathrm{Y}$ & $\mathrm{Y}$ & $\mathrm{Y}$ & $\mathrm{Y}$ & $\mathrm{Y}$ & $\mathrm{N}$ \\
\hline Work offline & $\mathrm{N}$ & $\mathrm{N}$ & $\mathrm{Y}$ & $\mathrm{Y}$ & $\mathrm{Y}$ & $\mathrm{N}$ & $\mathrm{Y}$ & $\mathrm{N}$ \\
\hline
\end{tabular}

iii. Student Involvement Tools

\begin{tabular}{|l|l|l|l|l|l|l|l|l|}
\hline Group work & $\mathrm{N}$ & $\mathrm{N}$ & $\mathrm{Y}$ & $\mathrm{Y}$ & $\mathrm{Y}$ & $\mathrm{Y}$ & $\mathrm{Y}$ & $\mathrm{Y}$ \\
\hline Student community building & $\mathrm{Y}$ & $\mathrm{Y}$ & $\mathrm{Y}$ & $\mathrm{Y}$ & $\mathrm{Y}$ & $\mathrm{Y}$ & $\mathrm{Y}$ & $\mathrm{Y}$ \\
\hline Student portfolios & $\mathrm{N}$ & $\mathrm{N}$ & $\mathrm{Y}$ & $\mathrm{Y}$ & $\mathrm{Y}$ & $\mathrm{Y}$ & $\mathrm{Y}$ & $\mathrm{Y}$ \\
\hline
\end{tabular}

Note: $Y=Y e s, N=$ No

Source: Created by author, based on literature review

TABLE 2. COMPARING DIFFERENT PLATFORMS ACCORDING TO SUPPORT TOOL

\begin{tabular}{|l|l|l|l|l|l|l|l|l|}
\hline Tool/Platform & Docebo & Schoology & Blackboard & Moodle & $\begin{array}{l}\text { ATutor } \\
2.0\end{array}$ & Edmodo & D2L & $\begin{array}{l}\text { Google } \\
\text { Site }\end{array}$ \\
\hline
\end{tabular}

i. Administration Tools

\begin{tabular}{|l|l|l|l|l|l|l|l|l|}
\hline Authentication & $\mathrm{Y}$ & $\mathrm{Y}$ & $\mathrm{Y}$ & $\mathrm{Y}$ & $\mathrm{Y}$ & $\mathrm{Y}$ & $\mathrm{Y}$ & $\mathrm{Y}$ \\
\hline $\begin{array}{l}\text { Course } \\
\text { authorization }\end{array}$ & $\mathrm{Y}$ & $\mathrm{Y}$ & $\mathrm{Y}$ & $\mathrm{Y}$ & $\mathrm{Y}$ & $\mathrm{Y}$ & $\mathrm{Y}$ & $\mathrm{Y}$ \\
\hline Hosted services & $\mathrm{Y}$ & $\mathrm{N}$ & $\mathrm{Y}$ & $\mathrm{Y}$ & $\mathrm{Y}$ & $\mathrm{N}$ & $\mathrm{Y}$ & $\mathrm{Y}$ \\
\hline $\begin{array}{l}\text { Registration } \\
\text { integration }\end{array}$ & $\mathrm{N}$ & $\mathrm{N}$ & $\mathrm{Y}$ & $\mathrm{Y}$ & $\mathrm{Y}$ & $\mathrm{Y}$ & $\mathrm{Y}$ & $\mathrm{Y}$ \\
\hline
\end{tabular}

\section{ii. Course Delivery Tools}

\begin{tabular}{|l|l|l|l|l|l|l|l|l|}
\hline Test types & $\mathrm{Y}$ & $\mathrm{Y}$ & $\mathrm{Y}$ & $\mathrm{Y}$ & $\mathrm{Y}$ & $\mathrm{Y}$ & $\mathrm{Y}$ & $\mathrm{Y}$ \\
\hline $\begin{array}{l}\text { Automated testing } \\
\text { support }\end{array}$ & $\mathrm{N}$ & $\mathrm{N}$ & $\mathrm{Y}$ & $\mathrm{Y}$ & $\mathrm{Y}$ & $\mathrm{Y}$ & $\mathrm{Y}$ & $\mathrm{Y}$ \\
\hline Course management & $\mathrm{Y}$ & $\mathrm{Y}$ & $\mathrm{Y}$ & $\mathrm{Y}$ & $\mathrm{Y}$ & $\mathrm{Y}$ & $\mathrm{Y}$ & $\mathrm{Y}$ \\
\hline Online grading tools & $\mathrm{Y}$ & $\mathrm{Y}$ & $\mathrm{Y}$ & $\mathrm{Y}$ & $\mathrm{Y}$ & $\mathrm{Y}$ & $\mathrm{Y}$ & $\mathrm{Y}$ \\
\hline Student tracking & $\mathrm{Y}$ & $\mathrm{Y}$ & $\mathrm{Y}$ & $\mathrm{Y}$ & $\mathrm{Y}$ & $\mathrm{Y}$ & $\mathrm{Y}$ & $\mathrm{N}$ \\
\hline
\end{tabular}

\section{iii. Content Development Tools}

\begin{tabular}{|l|l|l|l|l|l|l|l|l}
\hline Accessibility compliance & $\mathrm{Y}$ & $\mathrm{Y}$ & $\mathrm{Y}$ & $\mathrm{Y}$ & $\mathrm{Y}$ & $\mathrm{Y}$ & $\mathrm{Y}$ & $\mathrm{Y}$ \\
\hline Content sharing/Reuse & $\mathrm{Y}$ & $\mathrm{Y}$ & $\mathrm{N}$ & $\mathrm{Y}$ & $\mathrm{Y}$ & $\mathrm{Y}$ & $\mathrm{Y}$ & $\mathrm{Y}$ \\
\hline
\end{tabular}




\begin{tabular}{|l|l|l|l|l|l|l|l|l|}
\hline Course templates & $\mathrm{Y}$ & $\mathrm{Y}$ & $\mathrm{Y}$ & $\mathrm{Y}$ & $\mathrm{Y}$ & $\mathrm{Y}$ & $\mathrm{Y}$ & $\mathrm{Y}$ \\
\hline Customized look/feel & $\mathrm{Y}$ & $\mathrm{Y}$ & $\mathrm{Y}$ & $\mathrm{Y}$ & $\mathrm{Y}$ & $\mathrm{Y}$ & $\mathrm{Y}$ & $\mathrm{Y}$ \\
\hline Instructional design & $\mathrm{Y}$ & $\mathrm{Y}$ & $\mathrm{Y}$ & $\mathrm{Y}$ & $\mathrm{Y}$ & $\mathrm{Y}$ & $\mathrm{Y}$ & $\mathrm{Y}$ \\
\hline $\begin{array}{l}\text { Instructional standards } \\
\text { compliance }\end{array}$ & $\mathrm{Y}$ & $\mathrm{Y}$ & $\mathrm{Y}$ & $\mathrm{Y}$ & $\mathrm{Y}$ & $\mathrm{Y}$ & $\mathrm{Y}$ & $\mathrm{Y}$ \\
\hline
\end{tabular}

Source: Created by author, based on literature review

TABLE 3. COMPARING DIFFERENT PLATFORMS ACCORDING TO TECHNICAL SPECIFICATIONS

\begin{tabular}{|c|c|c|c|c|c|c|c|c|}
\hline Tool/Platform & Docebo & Schoology & Blackboard & Moodle & $\begin{array}{l}\text { ATutor } \\
2.0\end{array}$ & Edmodo & D2L & $\begin{array}{l}\text { Google } \\
\text { Site }\end{array}$ \\
\hline \multicolumn{9}{|c|}{ i. $\quad$ Hardware-Software Tools } \\
\hline $\begin{array}{l}\text { Client browser } \\
\text { required }\end{array}$ & $\bar{Y}$ & $\bar{Y}$ & $\mathrm{Y}$ & $\mathrm{Y}$ & $\mathrm{Y}$ & $\mathrm{Y}$ & $\mathrm{Y}$ & $\mathrm{Y}$ \\
\hline $\begin{array}{l}\text { Database } \\
\text { requirements }\end{array}$ & $\mathrm{N}$ & $\mathrm{N}$ & Y & $\mathrm{Y}$ & $\mathrm{Y}$ & $\mathrm{N}$ & $Y$ & $\mathrm{Y}$ \\
\hline Unix server & $\mathrm{N}$ & $\mathrm{Y}$ & $\mathrm{Y}$ & $\mathrm{Y}$ & $\mathrm{Y}$ & $\mathrm{N}$ & $\mathrm{N}$ & $\mathrm{N}$ \\
\hline $\begin{array}{l}\text { Windows } \\
\text { server }\end{array}$ & $\mathrm{Y}$ & $\mathrm{N}$ & $\mathrm{Y}$ & $\mathrm{Y}$ & $\mathrm{Y}$ & $\mathrm{Y}$ & $\mathrm{Y}$ & $\mathrm{Y}$ \\
\hline \multicolumn{9}{|c|}{ ii. Pricing/License Tool } \\
\hline $\begin{array}{l}\text { Company } \\
\text { profile }\end{array}$ & $\mathrm{Y}$ & $\mathrm{Y}$ & $Y$ & $\mathrm{~N}$ & $\mathrm{Y}$ & $Y$ & $Y$ & $\mathrm{~N}$ \\
\hline Costs & $\mathrm{Y}$ & $\mathrm{Y}$ & $\mathrm{Y}$ & $\mathrm{N}$ & $\mathrm{Y}$ & $\mathrm{N}$ & $\mathrm{N}$ & $\mathrm{N}$ \\
\hline Open source & $\mathrm{N}$ & $\mathrm{N}$ & $\mathrm{N}$ & $\mathrm{Y}$ & $\mathrm{Y}$ & $\mathrm{N}$ & $\mathrm{N}$ & $\mathrm{N}$ \\
\hline Optional extras & $\mathrm{Y}$ & $Y$ & $Y$ & $Y$ & $Y$ & $Y$ & $Y$ & $Y$ \\
\hline
\end{tabular}

Source: Created by author, based on literature review

\section{E-LEARNING IN MIDDLE EAST}

E-Learning is considered the most captivating current method of education in Middle East. The explanation is poor financial condition, cultural and social obstructions and absence of a capable and entrancing technique for learning. Historically, the main fundamental reason for the delay applying elearning system in Middle East nations is the absence of money-related sources to obtain expensive installations. However, the increment in the oil cost in 1970s, made a portion of the nations in this piece of the world empowered to tackle this issue somewhat. These nations contrast with other developed nations have been enabled to construct new schools and furnish them with new innovations (Ahmad et al., 2018). The second obstacle for the acknowledgment of these new innovations is the cultural and social counteraction of Middle East countries where these societies are reluctant to new changes and overestimate the negative parts of e-learning. On the other hand, Internet has had the option to introduce another view and significance for some of Islamic ideas, for example, Hijab (Veil), Meraj 
(Ascension), Hijrat (Migration), worldwide fellowship, and the concept of equality among genders. Thus, it ought to be said that E-learning has somehow toppled social and cultural hindrances and have been more accepted among societies (Ahmad et al, 2018).

In UAE, Female learners at Zayed University are not permitted to be available nearby the campus neither after working hour of the day nor on end of the weekdays. Usage of LMS makes it feasible for such students to associate with employees anytime. When gone up against with a male employee, females may likewise feel somewhat timid while taking part in-class conversations (Mirza \& AlAbdulkareem, 2011). Furthermore, the two purposes behind youthful age's excitement towards learning through Internet are: little expense and loads of fascination (Ahmad et al, 2018). Moreover, a study done in Zayed University in 2008 shows that $74.2 \%$ of the students had a pleasant feeling in using discussion blogs and chat rooms online. $71.2 \%$ felt more confidence in communicating their thoughts. Plus, $85.6 \%$ of the study group was happy with the online class condition (Mirza \& Al-Abdulkareem , 2011).

Hamdan Bin Mohammed Smart University Dubai (HBMSU) is a virtual foundation set up in 2002. The UAE Ministry of Higher Education licensed HBMSU as a research college that provides online learning programs through the use mobile learning, online study halls, discussion sites, real world video games, and social media (Al-Odeh, 2020). To achieve licensing, the first step was to gain the Ministry of Education accreditation, which at that time didn't have accreditation guidelines for online education. Hence, HBMSU cooperated with the University of Bradford, UK, to offer joint projects until new accreditation guidelines were discharged in 2005 and the college got accreditation and endorsement of their online programs in 2006 after proving the positive effect of online education (Al-Odeh, 2020). The subsequent stage was to prepare faculty members in utilizing instructional innovations and online devices. Staff upgraded their courses utilizing cutting edge innovations. The third stage was helping and encouraging learners to get adapted to the new online programs. The fourth stage was translating reading material into Arabic and the last stage was observing, controlling, and improving the procedure (Al-Odeh, 2020).

In Jordan, the Jordan education initiative project (JEI), developed in 2003, concentrated on building a partnership with Cisco systems to develop an online learning system. However, the main shortcoming was the limitations in infrastructure that didn't support interaction between students or between students and their teachers (Ahmad et al., 2018). Nevertheless, today Moodle is utilized in the University of Jordan to structure a well-designed e-learning system and LMS. LMS clients at the University of Jordan are arranged into five classifications as indicated by their specialists: administrator members, makers, redrafting instructors, non-redrafting educator, learners and visitors where everyone has various jobs. 
The University of Jordan online courses program is embraced from Khan's system (Figure 3) (Almarabeh et al., 2014).

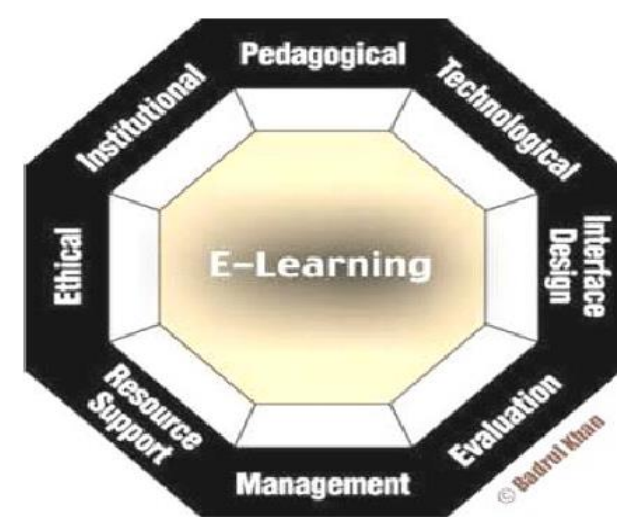

FIGURE 3. KHAN'S E-LEARNING FRAMEWORK

Source: Almarabeh et al (2014)

The Saudi government firstly introduced the e-learning in 2002. These courses were intended for individuals who were keen on specialized and professional preparing. So as to guarantee the accomplishment of this program, an e-library within excess of 50,000 books and 3,000 training programs was developed (Al-Odeh, 2020). In 2008, the Ministry of Higher Education (MOHE) likewise propelled the Google Educational Program. This activity at present includes 1,200 schools and in excess of 20,000 educator. MOHE has additionally marked updates of comprehension with Intel and Microsoft to build up a few instructive, preparing and e-learning programs for learners and instructors (Al-Asmari \& Khan, 2014). In 2003, colleges, for example, Um AlQura University and King Fahad University of Petroleum and Minerals built up e-learning focuses to help conventional projects to profit by instructional innovation by offering mixed courses. In 2007, the National Center for E-learning (NCEL) was built up to help e-learning frameworks; however, there were no online projects offered or certified. In 2009, the Ministry of Higher Education and NCEL sorted out the principal global gathering about e-learning and declared their acknowledgment of online projects. Afterward, in 2010, the Ministry of Higher Education formally endorsed the online learning offered in the Saudi colleges. In 2011, the Saudi Electronic University was set up as the primary electronic college in the nation to offer completely on the web and mixed trainings with coordinated effort from establishments, for example, eCampus Ohio University, University of Phoenix, Franklin University, Capella University, and Walden University. Presently, the college is accomplishing accreditation by national and universal associations to improve their nature of instruction and stay up with the latest with headways in advancements (Al-Odeh, 2020). 
In Kuwait, the first online institution in the Arab world was established in 2000 named Arab Open University (AOU). AOU penetrated many markets to open branches in Jordan, Bahrain, Saudi Arabia, Egypt and Lebanon (Matar et al., 2011). The main platform used by AOU was Moodle where the university established a partnership with the Open University in UK and provides a dual degree (ElGhali \& Ghosn, 2019).

In Lebanon, AOU provides its students a Lebanese and British degree whether online or on-campus. Other than that, AOU offers trainings online using video and audio presentations with online assessments. In 2017, American University of Beirut (AUB) accepted to present an online program to refugees in association with the University of Ottawa through a blended learning process (El-Ghali \& Ghosn, 2019). In mid-2020, the Lebanese Ministry of Education initiated the National Distance Learning project for the first time due to Covid-19 damage. The main strategies used were WhatsApp, Zoom free version package providing 40 minute classes, emails, and some LMS (Wazzan, 2020). However, Lebanon faces a lot of challenges that hinder the application of online learning. These challenges are summarized in Table 4.

TABLE 4. ONLINE LEARNING CHALLENGES IN LEBANON

\begin{tabular}{|c|c|c|}
\hline $\begin{array}{l}\text { University and Governmental } \\
\text { Challenges }\end{array}$ & Faculty Challenges & Students Challenges \\
\hline Political insecurity & Increase in student cheating & $\begin{array}{l}\text { Low interaction with instructors and } \\
\text { colleagues }\end{array}$ \\
\hline $\begin{array}{l}\text { Lack of online program } \\
\text { accreditation }\end{array}$ & High control by administration & Students' demotivation \\
\hline Unfamiliarity with e-learning & Lack of self-determination & Hard to handle technology \\
\hline Cultural rejection of online learning & Inability to assist students online & Unavailability of enough supplies \\
\hline $\begin{array}{l}\text { Inadequacy and ineffectiveness for } \\
\text { all age groups }\end{array}$ & Unwillingness to accept e-learning & Students' non-commitment \\
\hline Poor connection and lack of proper & & \\
\hline
\end{tabular}

Source: El-Ghali \& Ghosn (2019)

\section{METHODOLOGY AND SAMPLING}

One of the main issues to consider in online learning is students' satisfaction. In order to adhere to such information, it was essential to take the opinion of university students on the use of different learning platforms in Lebanon.

Data was collected by adopting a quantitative method through distributing a survey using email and social media groups. The survey targeted different universities in Lebanon: Lebanese American 
University, Lebanese International University, American University of Beirut, Arab Open University, American university of Science and Technology, American University of Culture and Education, Beirut Arab University, Lebanese University, and Universite Saint-Joseph. The sample was selected randomly and constituted of 609 male and female Lebanese students from different faculties and degree program. Major engaging faculties include faculties of business, health science, arts and science, education, engineering, and pharmacy.

The survey intended to give an insight about students' satisfaction with the platform, assessment used and online learning in general, to highlight on the reason for not attending online sessions and whether they need more training or not, and to understand whether they were fully attentive during lecturing.

\section{DATA FINDINGS AND ANALYSIS}

More females $(73 \%)$ than males (27\%) participated in the survey with an age range of $17-24$ years (90\%). $78 \%$ were undergraduate and $22 \%$ were graduate students. The main students' majors were divided as shown in the chart below (Figure 4).

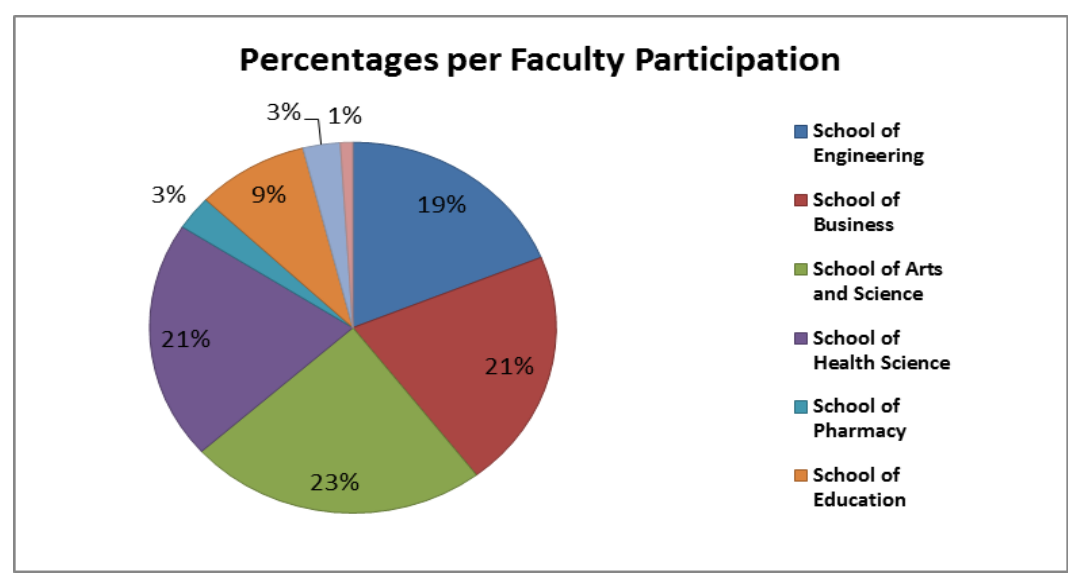

FIGURE 4. STUDENTS PER FACULTY

Source: Created by author

When studying the tools used in Lebanon by different universities, it was shown that three main platforms were utilized: Zoom, Google Classroom, and Moodle (Figure 5). 


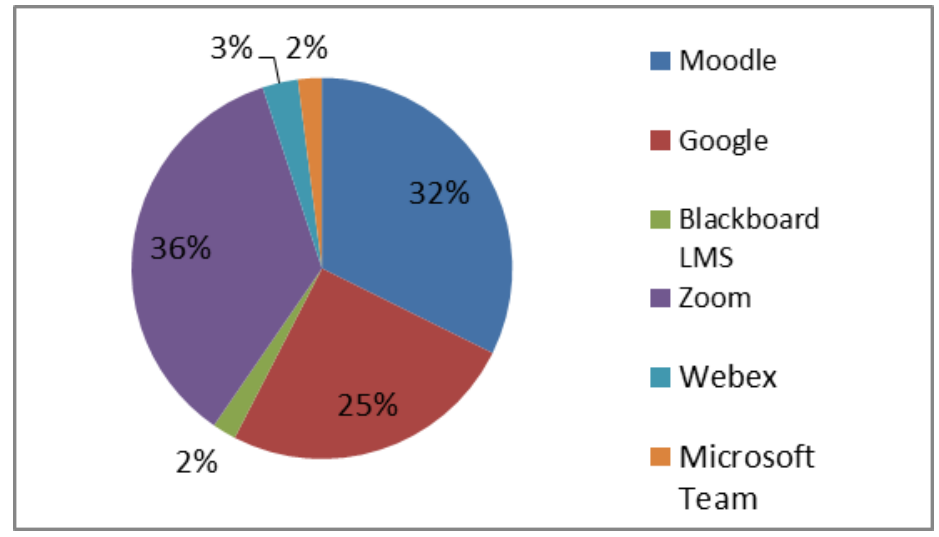

FIGURE 5. PERCENTAGES OF PLATFORMS USED

Source: Created by author

Online sessions were conducted for students where $72 \%$ were attending, $19 \%$ were not attending and $9 \%$ stated not applicable and when asked about their rate of satisfaction with online sessions, $42 \%$ were neutral, $19 \%$ were very satisfied, $23 \%$ were slightly satisfied, $12 \%$ were not at all satisfied, and $4 \%$ stated not applicable. As a new concept applied in Lebanon, online session satisfaction by students is shown to be acceptable. Thus, students are able to understand their instructors' course explanation.

Investigating the reason for not fully attending the online sessions, out of 607 students $37 \%$ had internet connection problems, $12 \%$ had electricity problems, $11 \%$ had a problem waking up early, $8 \%$ were distracted by their families, $7 \%$ had a job and $25 \%$ had no problem attending their online sessions. In addition, $88 \%$ were depending Wi-Fi to login to their accounts while only $12 \%$ used their $3 \mathrm{G}$ connection. The lack of electricity can be translated into internet connection problems as most of the students depend on Wi-Fi connection and lack the financial ability to keep using their $3 \mathrm{G}$ connection.

When asking students about their situation while being online, $55 \%$ stated that they sat alone and listened actively, 31\% were not fully attentive due to environmental distraction, $7 \%$ logged-in just for their instructor to see them online but don't listen at all, and 7\% didn't attend to their sessions. This reflects students' interest in listening and being actively present during online session.

Most universities uploaded previously recorded voice-over slides for students who have problem attending online sessions; however, it was shown that $21 \%$ were not satisfied at all while $30 \%$ were neutral, $27 \%$ very satisfied, $5 \%$ extremely satisfied, $14 \%$ slightly satisfied, and $3 \%$ not applicable. The main problems with recorded voice-over slides are the lack of interaction, problems in download speed, in addition to the inability to provide enough explanation and examples which can also affect the size of the file uploaded. Moreover, while $32 \%$ preferred to listen to the voice-overs after 6:00 PM, 33\% preferred the AM timing and 25\% between 1:00 PM and 5:00 PM, and 10\% had no preference. This shows that the majority of students prefer to study before 6:00 PM. 
Regarding assessments, 92\% were assessed online, whether through quizzes, exams, or assignments, out of which $7 \%$ were extremely satisfied, $40 \%$ were neutrally satisfied, $23 \%$ were very satisfied, $14 \%$ were slightly satisfied, and $16 \%$ were not at all satisfied. This reflects students' acceptability of online assessment although the majority (67\%) was given 1-3 hours to solve their assessments while $10 \%$ were given $4-6$ hours, $2 \%$ had $7-10$ hours, $15 \%$ had 24 hours, and $6 \%$ had more than 24 hours. This shows that students had no problem limiting their time to submit their assessments and were satisfied with the types of questions used (Figure 6).

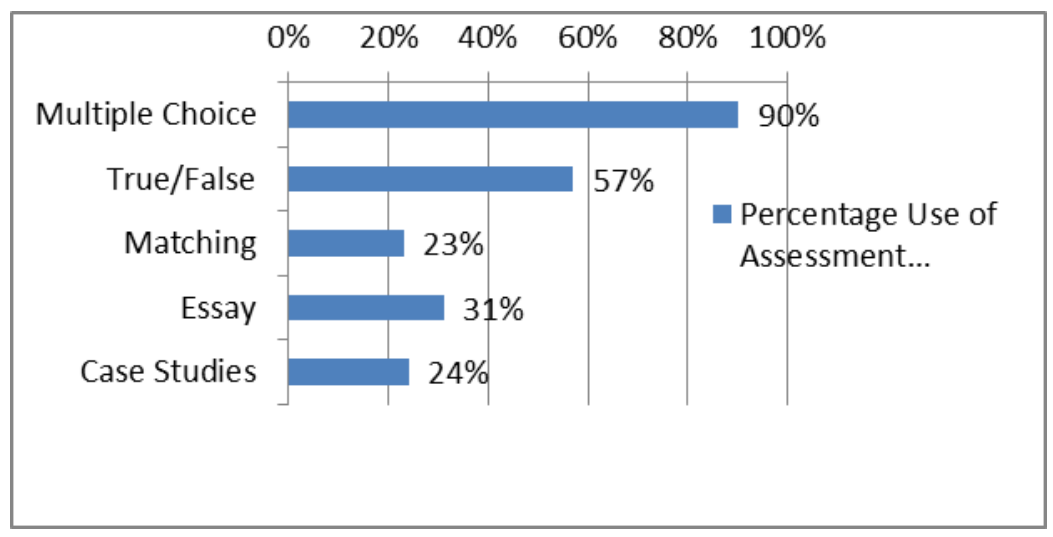

FIGURE 6. PERCENTAGES OF ASSESSMENT QUESTIONS USAGE

Source: Created by author

When assessing the level of interaction with instructors, $18 \%$ considered that there was high interaction and $4 \%$ extremely high interaction, $33 \%$ were neutral, and $30 \%$ said that there was slight interaction while $15 \%$ had no interaction with their instructors at all. Because interaction is an important element in learning and the basic key to student understanding, $48 \%$ preferred to have a hybrid learning system (online + on-campus) and $38 \%$ on-campus learning while only $14 \%$ preferred only online learning.

As a new experience, only $24 \%$ found using technology as difficult while the rest $76 \%$ found it easy which means students didn't have technological problems practicing new learning tools and this reflects the trainings that was given by the institutions where $74 \%$ of the students found it effective enough to surf through the platform, $11 \%$ stated to be ineffective, and $15 \%$ stated that no training was given to them.

Furthermore, when students had to rate their satisfaction level regarding their experience in online learning, the results came as shown in the charts below (Figures 7, 8, \& 9). 
Hamade, L.

THE DIGITAL MOVE TOWARDS ONLINE LEARNING IN LEBANON

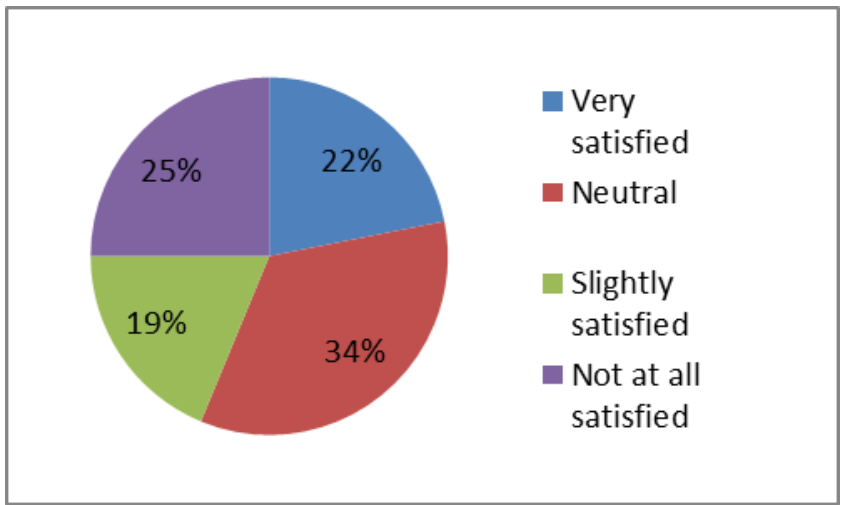

FIGURE 7. MOODLE SATISFACTION RATE

Source: Created by author

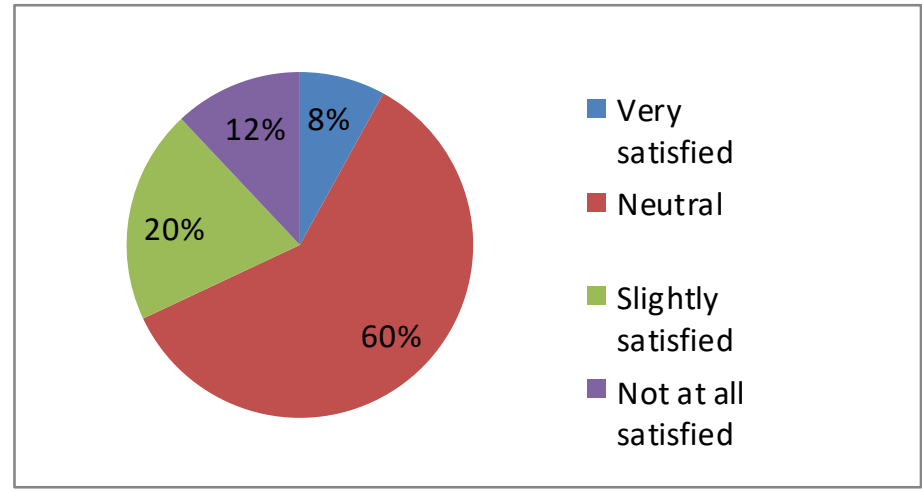

FIGURE 8. GOOGLE SATISFACTION RATE

Source: Created by author

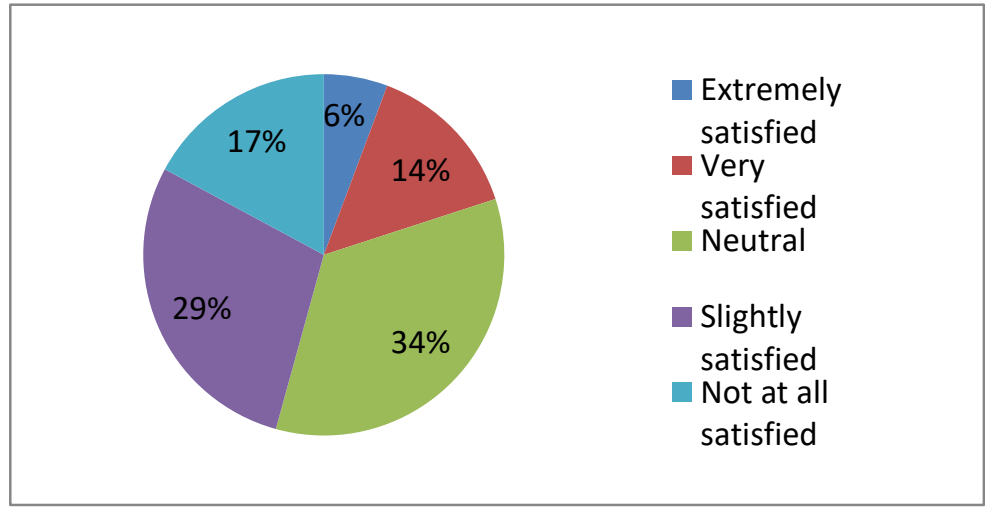

FIGURE 9. ZOOM SATISFACTION RATE

Source: Created by author

Comparing the dissatisfaction level among different platforms, the results came as following (Table 5): 


\section{TABLE 5. PERCENTAGES OF DISSATISFACTION PER PLATFORM}

\begin{tabular}{lrrl}
\hline Percentage & of Level of Interaction & Technology Difficulty & Assessment Satisfaction \\
Dissatisfaction & per & & \\
Platform & &
\end{tabular}

Platform

\begin{tabular}{llll}
\hline Moodle & $22 \%$ & $18 \%$ & $13 \%$ \\
Google & $12 \%$ & $17 \%$ & $8 \%$ \\
Zoom & $8 \%$ & $28 \%$ & $18 \%$ \\
\hline
\end{tabular}

Source: Created by author

When calculating the overall satisfaction rate of each platform, the results came as following: Moodle $51.04 \%$, Google $54.6 \%$, and Zoom $40.7 \%$. Therefore, there was a comparable satisfaction with Google Classroom and Moodle platforms. However, less satisfaction was noticed with Zoom.

Limitation of this study lies in the \% of students participating from different universities and their learning behavior. In addition, not all universities and majors participated in filling the survey. Besides, university management differs from one another which make the satisfaction level affected by what the particular university provided its students and how it dealt with the specific online platform they used. In addition, LMS platforms were adopted for first time by all university students due to Covid-19 quarantine.

\section{CONCLUSION AND RECOMMENDATION}

Online learning platforms are new tools not only adopted by young people whether in schools or universities; however, it is used by organizations of different sizes as a mean of communication whenever a distance is a problem and time efficiency is required.

Even though online learning is not accredited in Lebanon, the covid-19 pandemic obliged institutions to go through this new experience to satisfy the market, not to mention, e-learning is considered highly profitable to universities. That's a reason why educational institutions should work with governmental sector to provide accreditation for degrees acquired online. Additionally, governments are required to maintain an acceptable infrastructure from electricity and Wi-Fi connection and managing special prices for students and institutions on 3G-4G bundles used for LMS platforms, not to forget the importance of uploading digitalized books for students.

One of the main challenges of e-learning is distraction. To improve interaction and engagement, in-class and out-of-class analytical assignments should be posted for students to solve and submit, some daily and some others weekly, where the material should reflect book readings and concepts taken during online sessions. Analytical assignment will encourage students' discussion and group work. In addition, 
while home assignments can be sent for learners as bonus to encourage to study, solve and submit, inclass assignments can be also be provided as bonus for students to motivate them to attend classes and when discussed during online sessions will enhance students' engagement and understanding. Assignments can give an insight into the students' studying behavior and habit and whether they are gaining understanding from online sessions or not. On daily basis communication with students is another way to keep them engaged through posting announcements, sending emails, using the LMS white board, using chat and instant message tools.

Staffs' mentality should be shifted from online learning is ineffective to digital technology enhances the learning process. Video-sharing, recorded videos and presentations, real-time chat and discussion forums, whiteboards and many others can all be used to enhance learning experience whether learning is online or blended.

Another challenge to online learning is the cost of purchasing, installing and maintaining the software and hardware required to implement online learning. One of the ways to decrease in the cost is through training faculty members to improve their skills in using technologies. The faultier members are ready to use platforms, the more effective the strategy will be and the more students will be satisfied with less errors. Moreover, students should be provided with proper training through online seminars or videos on how-to-use the platform. Successful students' training will decrease the time load required to answer students' questions and responding to emails, in addition to minimizing the errors students can perform especially when it comes to submitting assignments and quizzes. Furthermore, free of charge platforms can be used with minimal technical specifications for an easy administration by staff and students.

In order to modify the way people in general think regarding digital technology in education, governments and different industry sectors should all work together to properly implement online learning system and show its effectiveness and benefits to society, economics, one's welfare.

\section{REFERENCES}

Ahmad, A., Nemeah, A., \& Mohammed, H. (2018). A review of adoption of e-learning in Middle East countries. Journal of Software Engineering \& Intelligene Systems, 3(1): 61-66.

Al-Ajlan, A., Zeidan, H. (2008.) Why Moodle: 12 th IEEE International Workshop on Future Trends of Distributed Computing Systems, 58-64. DOI 10.1109/FTDCS.2008.22

Al-Asmari, A., Khan, M. (2014). E-learning in Saudi Arabia: Past, present and future. Journal of Research in education. http://dx.doi.org/10.5339/nmejre.2014.2

Alim, N., Saad, M., Linda, W., \& Gunawan, F. (2019). The effectiveness of Google Classroom as an Instructional Media: A Case of State Islamic Institute of Kendari, Indonesia. Journal of humanities and Social Sciences, 7(2): 240-246.

Almarabeh, T., Mohammad, H., Yousef, R., \& Majdalawi, Y. (2014). The University of Jordan E- 
Learning Platform: State, Students' Acceptance and Challenges. Journal of Software Engineering and Application, 7: 999-1007. http://dx.doi.org/10.4236/jsea.2014.712087

Al-Odeh, M. (2020). What universities in the Middle East can learn from the American online education system. International Journal of Informatics and Communication Technology (IJ-ICT), 9(1): 31-39. DOI: $10.11591 /$ ijict.v9i1

Alokluk, J. (2018). The Effectiveness of Blackboard System, Uses and Limitations in Information

Management. Journal of Intelligent Information Management, 10: 133-149. https://doi.org/10.4236/iim.2018.106012

Bradford, P., Porciello, M., Balkon, N., Backus, D. (2007). The Blackboard Learning System: The Be All and End All in Educational Instruction? Journal of Educational Technology Systems, 35: 301-314.

El-Ghali, H., Ghosn, E. (2019). Towards Connected Learning in Lebanon. Issam Fares Institute for Public Policy and International Affairs at American University of Beirut. Retrieved on June 20, 2020 from http://www.aub.edu.lb/ifi

Matar, N., Hunaiti, Z., Halling, S., \& Matar, S. (2011). E-Learning Acceptance and Challenges in the Arab Region. IGI Global: 184-200. DOI: 10.4018/978-1-60960-048-8.ch013

Mirza, A., Al-Abdulkareem, M. (2011). Models of e-learning adopted in the Middle East. Applied Computing and Informatics, (9): 83-93. Doi:10.1016/j.aci.2011.05.001

Mohammed, A., Kumar, S., Maina, B., Shuaibu, A. (2017). E-Learning: A Tool for Enhancing Teaching and Learning in Educational Institutes. International Journal of Computer Science and Information Technologies, 8 (2): 217-221.

Monarch Media Inc. (2010). Open-Source Learning Management Systems: Sakai and Moodle.

Retrieved September 21, 2020 from https://www.monarchmedia.com/wpcontent/uploads/2015/01/open-source-Ims-sakai-and-moodle.pdf

Rahman, U. (2020). Uses of Google Classroom in Higher Education of Bangladesh. Higher education, $1(1), 3$.

Soni, A. (2015). Choosing the Right eLearning Methods: Factors And Elements. Retrieved on September 1, 2020 from http://amitksoni.com/choosing-the-right-elearning-methods-factors-andelements/\#.X2uyrDJR3Dc

Stern, J. (n.d.). Introduction to Online Teaching and Learning. University of Maryland. Retrieved on August 6, 2020 from http://www.wlac.edu/online/documents/otl.pdf

Subramanian, P., Zainuddin, N., Alatawi, S. (2014). A Study of Comparison between Moodle and Blackboard based on Case Studies for Better LMS. Journal of Information Systems Research and Innovation, 26-33.

TrustRadius. (2020). Learning Management Systems (LMS) Overview. Retrieved on September 2, 2020 from https://www.trustradius.com/learning-management-Ims

UCLES. (2017). Digital technologies in the classroom. Cambridge Assessment International Education. Retrieved on August 6, 2020 from https://www.cambridgeinternational.org//mages/271191-digitaltechnologies-in-the-classroom.pdf

Wazzan, M. (2020). Learning Remotely as the Only Resort: How is Lebanon Doing? Retrieved on August 5, 2020 from https://www.al-fanarmedia.org/2020/04/learning-remotely-as-the-only-resorthow-is-lebanon-doing/

Williams, B., Riordan, M., Dougiamas, M. (2007). Moodle manual for Teachers And Trainers. Retrieved on June 19, 2020 from http://eposproject.net/wpcontent/uploads/2017/01/Moodle_Guide2.pdf 
Hamade, L.

THE DIGITAL MOVE TOWARDS ONLINE LEARNING IN LEBANON

Zaki, H., Zawaidy, H. (2014). Using Blackboard in Online Learning at Saudi Universities: Faculty Member's Perceptions and Existing Obstacle. International Interdisciplinary Journal of Education, 3(7): 141-150. 